ISBN 978-81-936279-5-2

10th International Conference on Design, Architecture, Civil and Environment Engineering

(DACEE-18)

Zagreb (Croatia) May 11-12, 2018

\title{
Understanding the Performance of the Iraqi Traditional Courtyard House, Is there an Order for the Use of External Envelope Materials?
}

\author{
Mohamed M. Saeed Almumar ${ }^{1}$ and Muder Mohamed M. Almumar ${ }^{2}$ \\ ${ }^{1}$ M.Sc. in Architectural Technology, Lecturer, Ishik University, Erbil, Kurdistan Region, Iraq \\ ${ }^{2}$ B.Sc. in Civil Engineering, Independent Engineer, Florida, USA
}

\begin{abstract}
Until the late decades of the nineteenth century, The Iraqi traditional courtyard house (ITCH) had ensured social, cultural, and environmental needs. Although many researchers had documented the ITCH characteristics and features, the strategy of materials use of its walls and roof slabs has not been recorded as a system or an order yet. This paper believes that the ITCH has an inherent order for its walls and roof slabs materials use. The research methodology, to explore and extrapolate this order, includes investigating and analyzing photographic and descriptive surveys of the ITCH documentations. Results reveal that the order comprises the use of the two types of components; the thick and heavy walls and roof slab with the thin and lightweight ones together simultaneously in appropriate specific positions of the ITCH. The order also expresses a harmony between the material properties of the envelope components and their exposure to the environment. Thick and heavy walls and roof slab are used in places where they are mostly shaded, whereas thin and lightweight ones are used where they are exposed to sun. The order was simulated in a diagrammatic house model.
\end{abstract}

Keywords: Order, External envelope and internal divisions, Thick and heavy weight, Thin and lightweight, Walls and roofs, Wood and brick.

ITCH= Iraqi Traditional Courtyard House

\section{Introduction}

The Iraqi traditional courtyard house (ITCH), in this paper, is the townhouse that was built during or before the first decades of the twentieth century throughout Iraqi regions. Many researchers believe that the ITCH origin extends to the Sumerian house which was the result of the Mesopotamia civilization that revealed a progressive order harmonized with the local environment (al-Zargani, 2017). The Iraqi urban heritage has a historical, social, economic, aesthetic and scientific significance and contains much of urban principles that have been grown-up through trials during long history. These principles can be exploited to develop a local modern architecture (Shakiri, 2017). Although a renewed interest of the ITCH is on the rise, much of its valuable principles and knowledge were forgotten or put aside. One of the main reasons, for excluding the desire of the ITCH development, was the lack of adequate understanding of its performance. Nowadays, after one full century from the departure of the ITCH order, another reason arises that hinder the possibility of its development which is the incomplete documentation (al-Zarkani, 2012). This incomplete documentation that describes the ITCH system characteristics makes its perception difficult, ambiguous and foggy. A wide gap of knowledge occurs from this incompleteness that hindered access to a substantive evaluation of what has been made by the current Iraqi modern architecture (al-Fattal, n.d.). Since the ITCH was the practical solution to the local environment, borrowing the scientific thinking from the past may lead to a better future architectural design (Almusawi, 2014). Shahin (2011) suggested directing the scientific research towards finding an appropriate methodology to 
achieve communication with the values and concepts of our architectural heritage to develop a contemporary Iraqi architecture of a unique identity.

The current relevant literature reflects a common notion, that the important feature of the ITCH is its heavyweight and thick walls and roofs. This paper proved that this opinion comprises only a piece of reality, since a great part of the external envelope in a single house unit is lightweight and thin.

\section{Research Goal and Significance}

This paper intends to prove that there is an architectural order for the material of the ITCH external envelope which comprises the use of the components of contradicting properties; the thick and heavy walls and roof slab with the thin and lightweight ones together simultaneously in appropriate specific positions that ensure a harmony with their exposure to the environment.

Understanding the ITCH environmental performance can be achieved by enlightening its orders which constitutes an important analytical tool that can be invested to develop new architectural design methods.

\section{Methodology}

This paper believes that studying a specific single ITCH unit will not reveal the common sharing rules and conditions that constitute a system or an order due to the possible dissimilar properties of existing units. Therefore, the research methodology conducts various surveys for the current ITCH documentation. The gained data are classified and summarized in article 3.1 to illustrate the full alternatives of the ITCH walls and roof slabs characteristics. These properties were analyzed and investigated in article 3.2 to explore and verify the existence of a specific order for the ITCH external envelope. In article 3.3 the order was simulated in a diagrammatic house model documenting its full image.

\subsection{Data Collection from the Current Documentation}

Data collection included a photographic survey of existing ITCH units and studies of selected bibliographies conducted by archaeologists and scholars in Iraq and adjacent geographical areas. The common corporeal attributes of walls and roof slabs were extracted, summarized, and some of the selected ones were presented in Tables 1 to 4 . Tables 1 and 2 illustrate the photographic documentation for existing traditional houses in many Iraqi cities and neighboring regions of near climate respectively.

TABLE I: A Photographical Survey of Walls and Roof Slabs Properties for Existing Traditional Houses in Some Iraqi

Cities

\begin{tabular}{|c|c|c|c|c|c|c|}
\hline \multirow{3}{*}{$\begin{array}{c}\text { City, } \\
\text { municipality, } \\
\text { date. }\end{array}$} & \multirow[t]{3}{*}{ Examples } & \multicolumn{5}{|c|}{ Component Properties } \\
\hline & & \multicolumn{2}{|c|}{ Walls of } & \multicolumn{3}{|c|}{ Roof slab of } \\
\hline & & 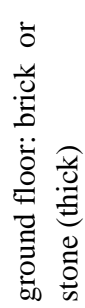 & 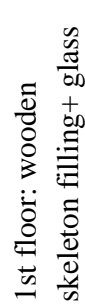 & 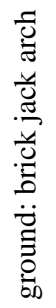 & 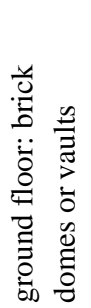 & 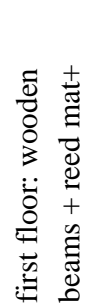 \\
\hline $\begin{array}{l}\text { 1.Baghdad } \\
\text { (Warren \& } \\
\text { Fathi, 1982) }\end{array}$ & (5a) & $\sqrt{ }$ & $\sqrt{ }$ & - & $\sqrt{ }$ & $\sqrt{ }$ \\
\hline
\end{tabular}




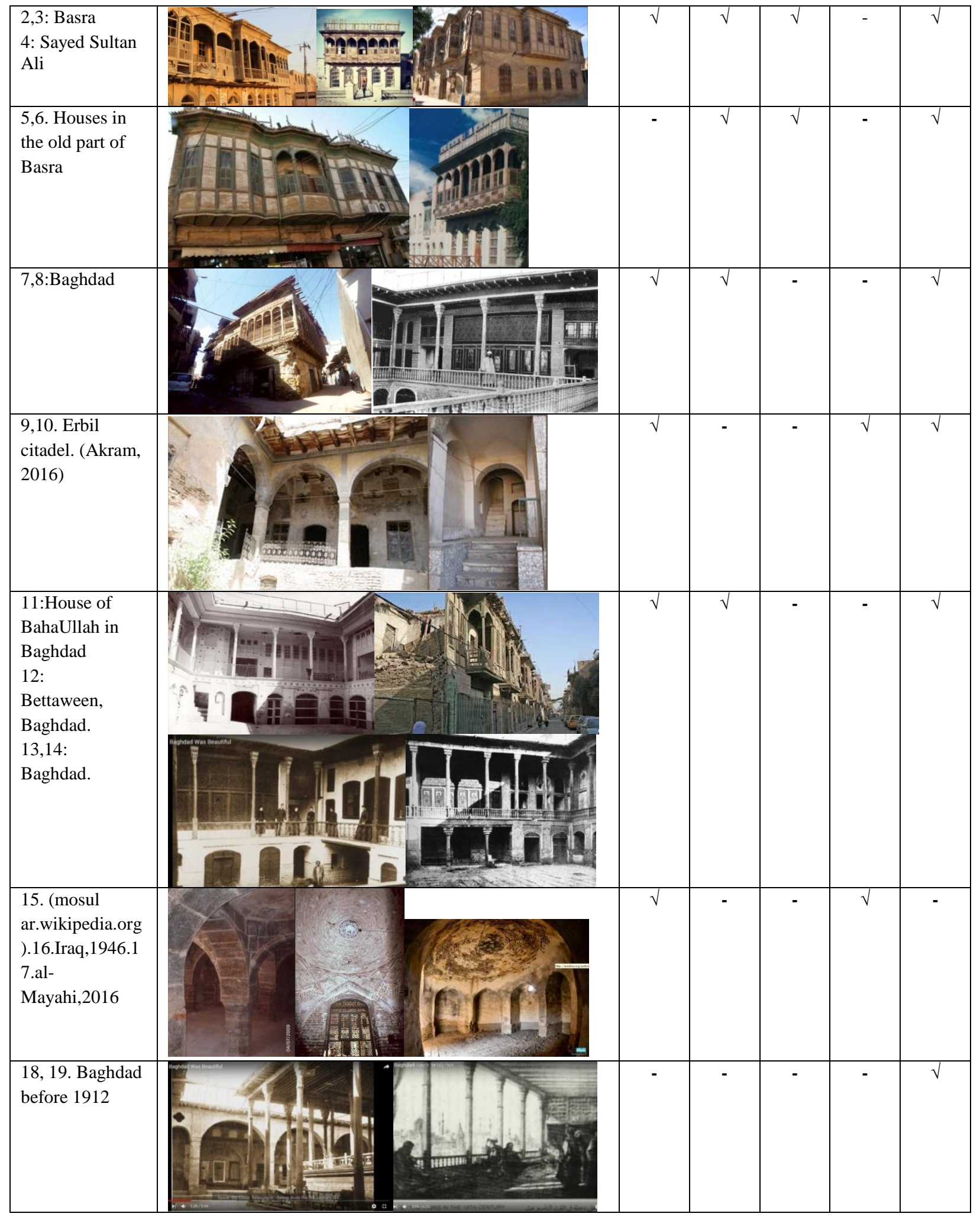




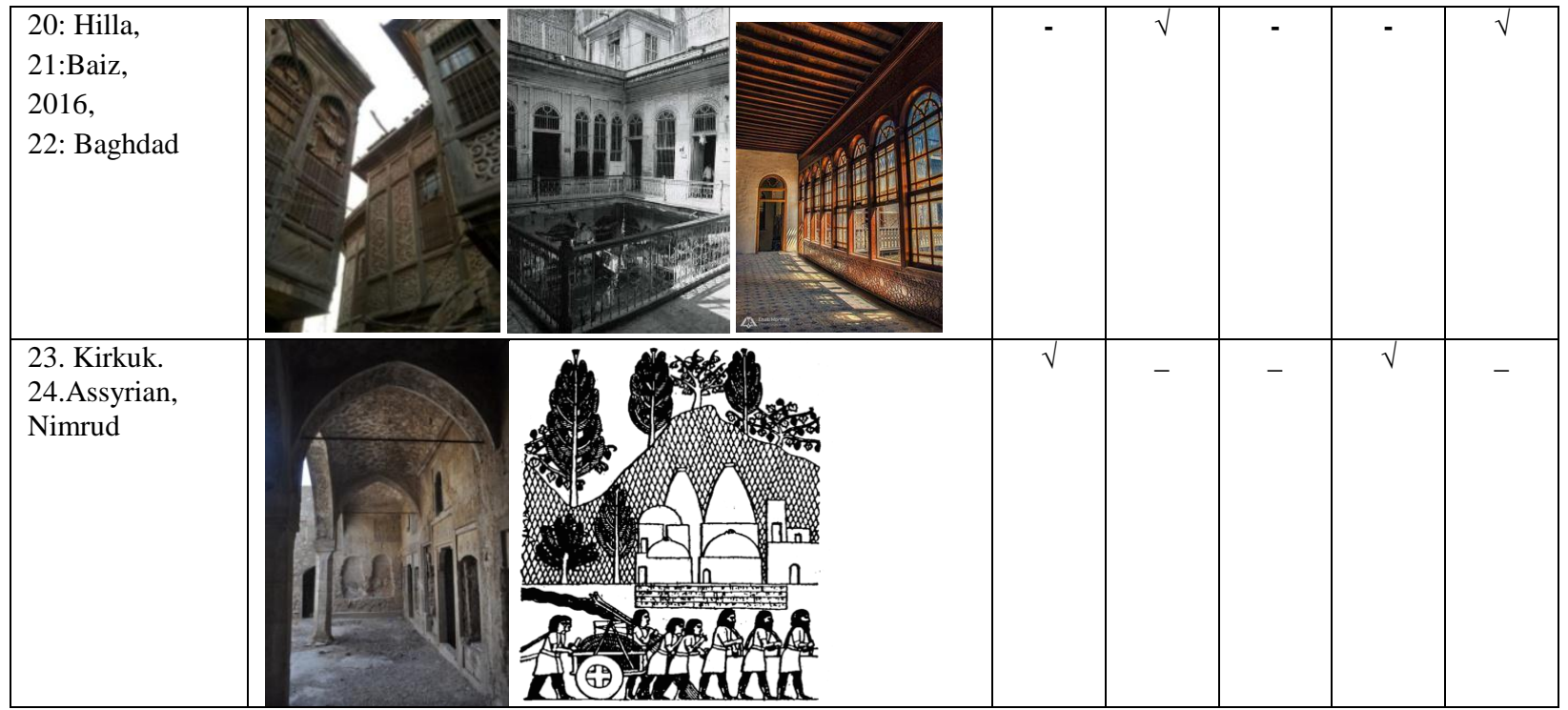

TABLE II: Walls and Roof Slabs Properties for Existing Traditional Houses in Some Neighboring Cities of Near Climate

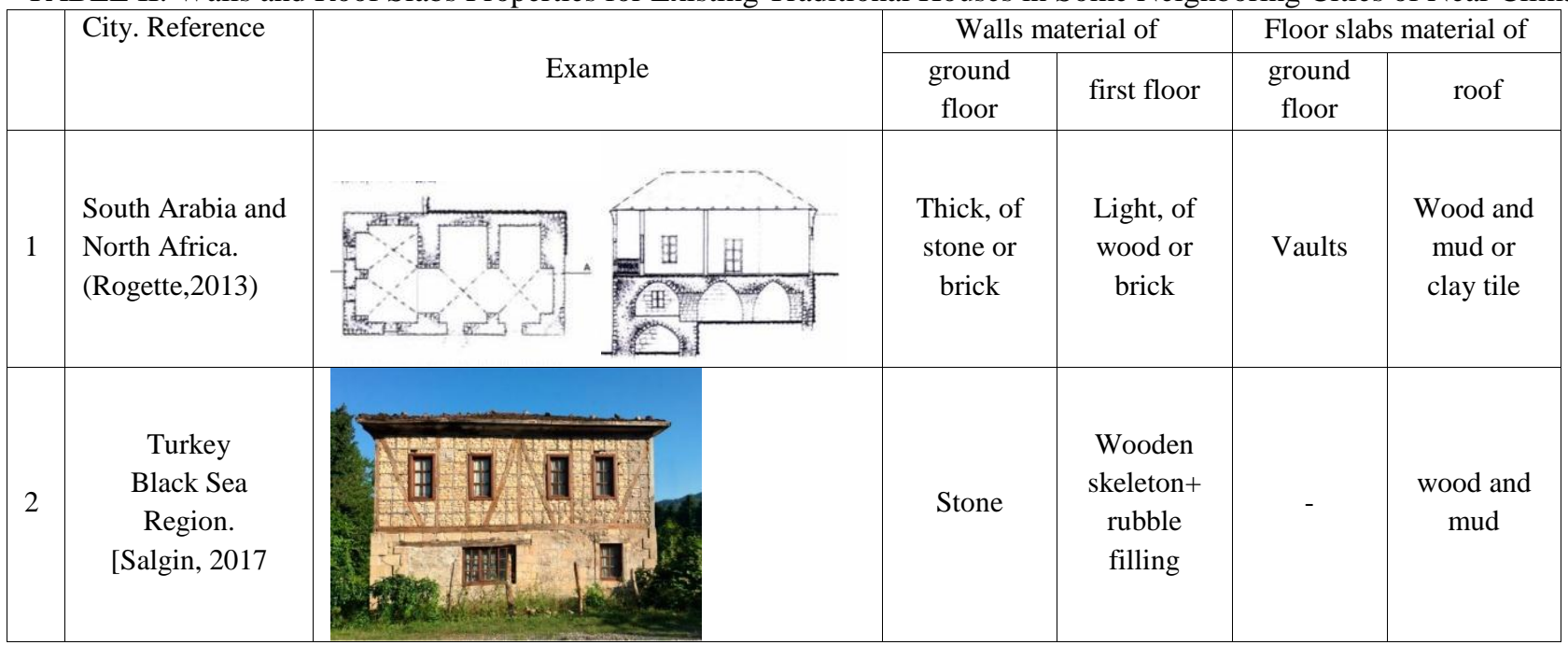

From Tables 1 and 2, some important characteristics of the ITCH walls and roof slabs can be summarized as follows; ground floor external walls are thick, made of brick or stone and have small openings. Whereas the first-floor external walls facing the courtyard and ally are mostly thin and made of wooden skeleton with wood or brick filling and of a high percentage of glass. They also reveal that all roofs are light and thin composed mainly of timber beams, pressed reed, reed mats and clay finish. About half of the ground floor roof slabs; when its details are visible in the photos, are made of brick Jack arching, and the other half are vaulted or domed by brick. Some of the ITCH units have thick walls in the first floor but of large openings as shown in cell 9 Tables 1

To explore the full picture of the ITCH external envelope characteristics, this paper adopted the descriptive documentation in addition to the photographic survey for the following reasons; first, the former extends for earlier periods which reveals primarily use of materials and techniques, unlike photographic ones which mostly represents houses constructed in late periods. As an example, some ITCH units used steel beams to roof ground floor spaces as shown in the photographic survey, the descriptive documentation showed that domes or vaults are used instead. Second, the detailed properties, such as walls thickness and construction details of the components which don't appear in photographs are described in the descriptive documentation. Tables 3 and 4 indicate the descriptive record. 
TABLE III: Records of Walls and Roof Slabs Properties in the Iraqi Traditional Courtyard House

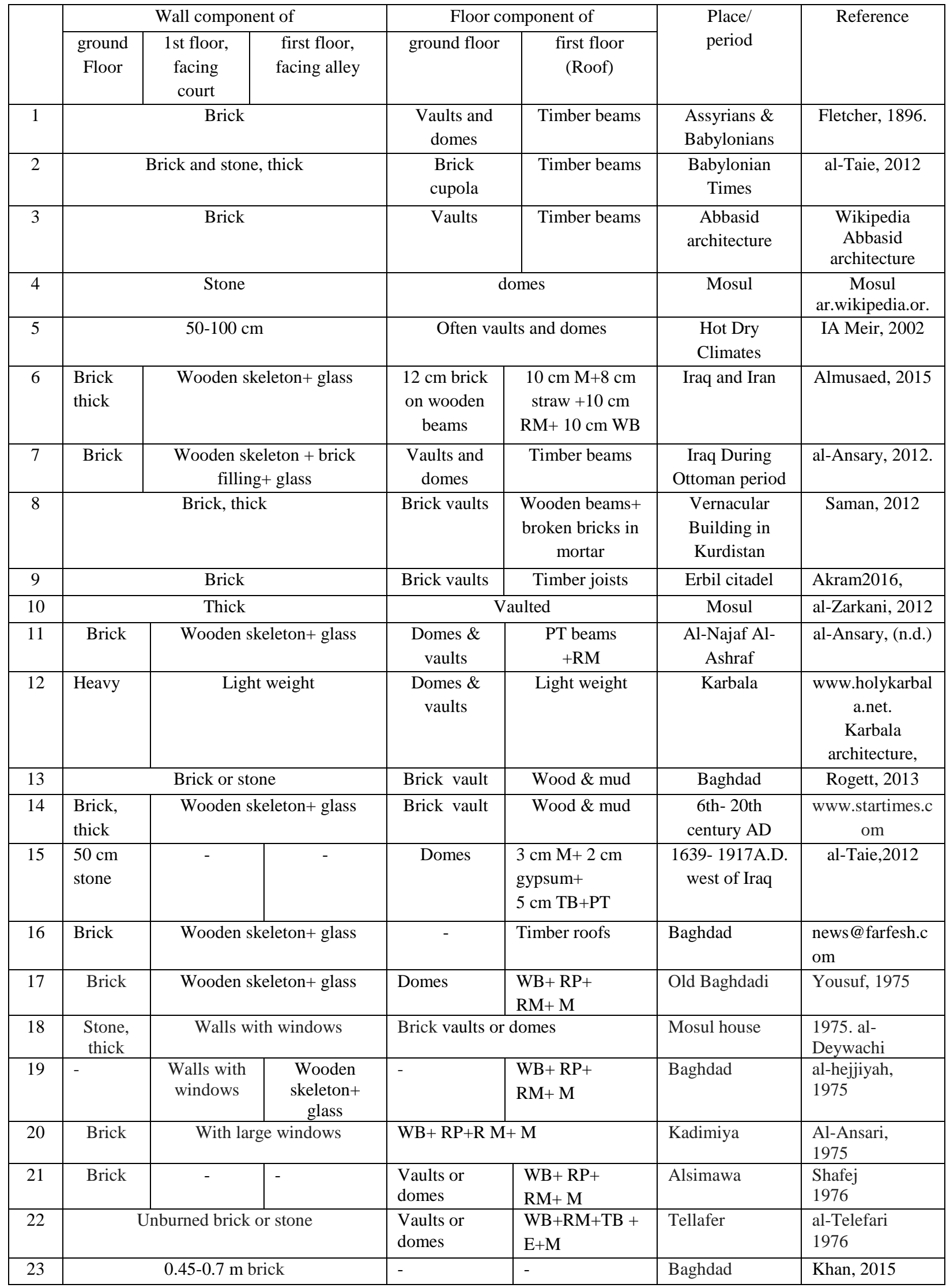

Note: WB=Wooden Beams, PT=Palm Trunk, TB=Tree Branches, RP=Reed Pack, RM=Reed Mat, M= Mud, CE=Clean Earth. 
TABLE IV: Records of Walls and Roof Slab Properties in Traditional House in Neighboring Cities

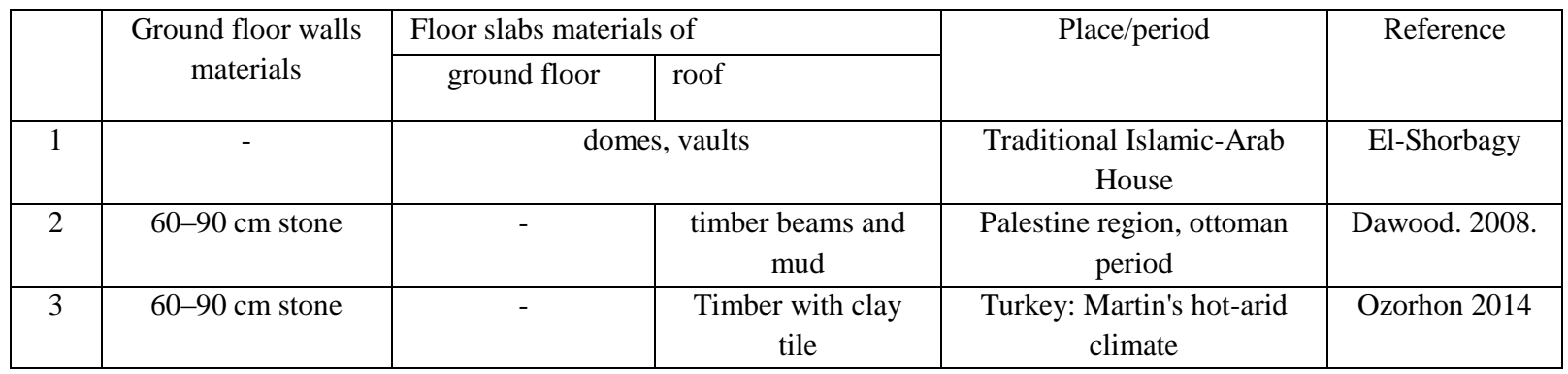

Generally, in tables 3, the ITCH walls and roof slabs characteristics were not described in details. Only $46 \%$ of the 23 samples described thickness of ground floor walls as 0.45 m-1.00 m or as thick. Similarly, $47 \%$ of the 23 samples described first floor walls as light panels of wooden skeleton and glass or as brick walls with large openings, and $25 \%$ of these walls had been described as of thickness similar to the ground floor walls as in cells; $2,5,8,10$, and 23. The remaining percentage has no declaration about their thickness. Most of the records indicate the dual use of heavyweight and thick ground roof slab with the lightweight and thin roofs together in a single unit. In some ITCH units, the two floor slabs are described as of similar types; as in cells; 4, 5, 10, 18, and 20. These dissimilarities of the properties are analyzed in the following article (3.2).

\subsection{Analysis}

It can be noted that, the current documentation did not recorded an order to the ITCH external envelope material use. The characteristics of walls and roof slabs, both the light and heavyweight, were derived from the conducted surveys. The paper relied on and adopted the most frequent characteristics that obtain semi-consensus or the largest proportion of frequency for all studied samples. Tables 3 and 4 reveal almost similar properties as in Tables 1 and 2, especially for the ground and first floor external walls but with different frequencies. Also, they show that $90 \%$ the ground roof slabs are recorded as heavyweight domes or vaults and thick, whereas $10 \%$ of them are recorded as lightweight and thin of wooden beams, reed mats, and mud. 84\% of roofs are recorded as lightweight and thin of wooden beams, reed mats, and mud, whereas $16 \%$ of them are recorded as heavyweight and thick of domes or vaults. Therefore, the two high frequencies properties of domes or vaults, and light wooden and mud roofs are adopted by this paper as ITCH properties for the ground floor roof slab and roof respectively.

When comparing the external envelope properties of the ITCH in Tables 1 and 2 with Tables 3 and 4, it was noted that there are some dissimilarities, specifically the use of brick jack arching for the ground floor roof slab in the photographic survey instead of brick domes or vaults. The use of jack arching can be justified by that some of these houses were constructed in late periods when the traditional system began to disintegrate and the use of modern building materials such as steel profiles took place.

Also, in Table 3, about half of the first floor walls are described as thick and of heavyweight instead of lightweight and thin panels in contradiction to Tables 1and 2 which show that $83 \%$ and $100 \%$ of the first-floor walls are lightweight and of thin panels respectively.

Thick and heavyweight walls were used especially in Kurdistan and Mosul area as shown in cells 4, 8, 9, 10, 18 , and 22 of table 3 which may be justified to the difference of the climate from that of other parts of Iraq. They were also used during ancient times as shown in cells 1, 2, and 3 when the ITCH order was still developing. They were also used in some other parts of Iraq when the economic conditions of the house owner is lower than the level of expenditure of construction, since wooden skeleton costs much more than a brick wall. Therefore, the research relied on the characteristics of lightweight and thin properties in documentation the first floor walls due predominance of the photographic survey, which represents reality, on the descriptive documentation. Full image of the ITCH characteristics is presented in article 3.3 . 


\subsection{Results, The Simulated Model}

This paper proved the dual use of thick and heavy weight with the thin and lightweight components together for walls and roofs simultaneously in a single ITCH unit. The two types of components are integrated to form a specific order of the ITCH external envelope as presented in Table 5.

TABLE V: ITCH External Envelope Order for Building Material Properties

\begin{tabular}{|c|c|c|c|}
\hline \multicolumn{2}{|c|}{ Component } & Material & Classification \\
\hline \multirow{3}{*}{ 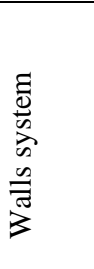 } & of ground floor & $45 \mathrm{~cm}-100 \mathrm{~cm}$ Brick.(Or) $50 \mathrm{~cm}$ stone. & Thick, heavy \\
\hline & $\begin{array}{l}\text { of first floor, } \\
\text { external }\end{array}$ & $\begin{array}{l}\text { Wooden skeleton with brick or wood filling and of a high } \\
\text { percentage of glass. } \\
\text { Or of brick or stone walls with high percentages of glass } \\
\text { (Mosul and Kurdistan) }\end{array}$ & Thin, light \\
\hline & Internal & $45 \mathrm{~cm}-100 \mathrm{~cm}$ Brick.(Or) $50 \mathrm{~cm}$ stone. & Thick, heavy \\
\hline \multirow[b]{2}{*}{ 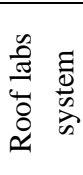 } & of ground floor & Vaults or domes of brick. & Thick, heavy \\
\hline & of first floor & $\begin{array}{l}\text { Timber beams+ tree branches+ reed mats+ clay finish.(Or) } \\
\text { Trunk palm beams+ pressed reed+ reed mats+ clay finish.(Or) } \\
\text { Vaulted or domed by brick in Mosul. }\end{array}$ & Thin, light \\
\hline
\end{tabular}

This paper developed a diagrammatic architectural model that simulates the order of materials use and characteristics of the ITCH external envelope. The model, which is depicted in figure 1, indicates that the heavy weight and thick components were used for ground floor roof slab and for ground floor walls which were applied with small openings to the outdoor. Whereas, light weight and thin components were used for the roof and the first floor external walls which were applied with large openings to the outdoor.

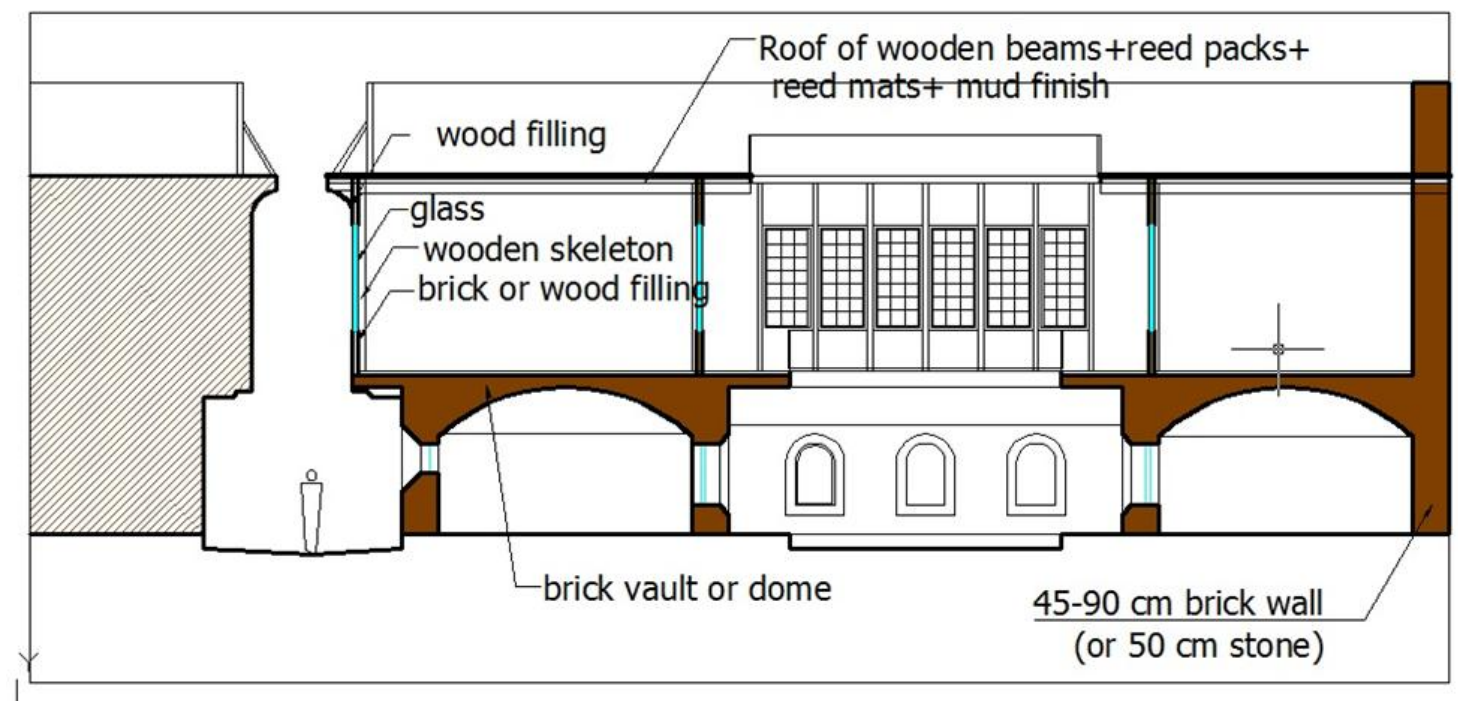

Fig 1. A Diagrammatic Model indicating the Order of ITCH Building Enclosure Materials Use

\section{Discussion}

This article studies the strategy of building material use of the ITCH enclosure, and investigates if there is a relation between the component physical characteristic with its relative location in the house. Figure 2 indicates two diagrammatic sectional views of the simulated model with the most possible exposure to sun in winter and summer. It can be noticed that the ground floor walls overlooking the alley and courtyard are mostly shaded throughout the year. Thus, thick and heavy weight material were used for these walls and equipped with small openings of glass to the outdoor. First floor walls overlooking the courtyard and alley which are exposed to direct sunlight most times of the year are made of lightweight and thin materials and contain a large portion of glass to admit sun and light to penetrate to rooms during winter. Similarly, roofs which are exposed completely 
to sun throughout the whole year, are made of lightweight and thin materials. It can be concluded that the material use strategy of the ITCH ensures an inherent relation between its physical characteristic and its relative location in the house.
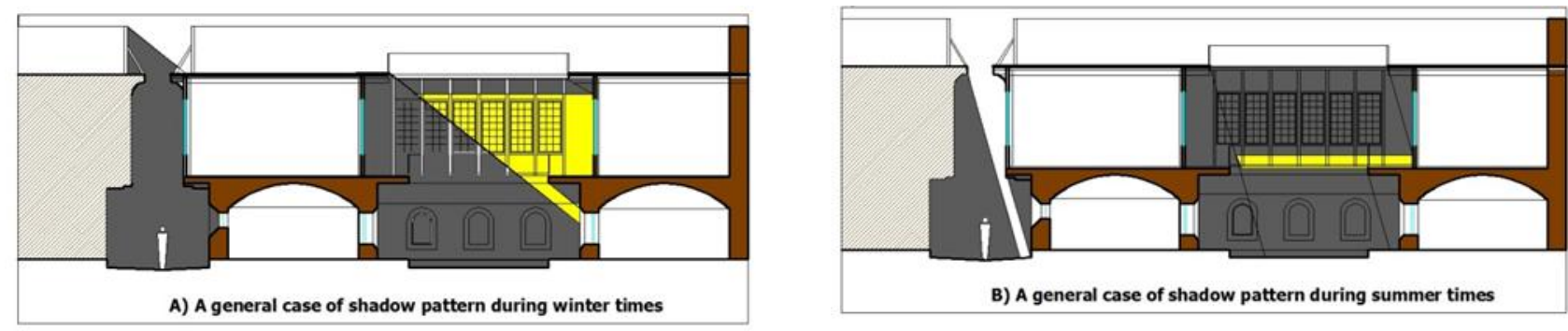

Fig 2: Diagrammatic sectional views showing: lightweight and thin materials for the components exposed to sun, thick and heavyweight material for the components in shade

\section{Conclusion}

This paper reveals the ITCH external envelope order which adopted the use of two converse properties of building components; the heavyweight and thick versus the lightweight and thin together in one unit. This strategy was integrated with outdoor space geometry that controls the external envelope exposure to sun. Places that are exposed to sun, thin and lightweight building components are used in order to be heated rapidly during winter daytimes and at the same time cool down rapidly during summer nights due to their low thermal resistance, storage, and delay properties. Inversely, places that are shaded, thick and heavyweight building components of small windows are used in order to keep the heat of winter daytimes for cold nights and at the same time keep the coolness of summer nights for hot daytimes due to their high thermal resistance, storage, and delay properties. Large windows are innate to walls that are exposed to and shaded from sun during winter and summer times respectively.

Understanding the ITCH orders which constitutes an important analytical tool can be invested to develop architectural design methods. Extended research is essential to understand the order of the ITCH courtyard geometry.

\section{References}

[1] Al-Zargani, K., 2017. Iraqi Vernacular Architecture. Alturath Alshaabi journal, issue 25.

[2] Shakiri, S., Zayani, M., Satif, D., Aljilfa, A., 2017. Sustainability of urban Heritage: Journal of the Arab scientific heritage, the first issue. $\mathrm{p} 58$.

[3] Al-Zarkani, K., 2012. Baghdad Lost Heritage. https://goo.g1/UxaF2N.

[4] Al-Fattal, S., n.d. Baghdad, those forgotten images. Culture and the media, Iraq. http://www.alhikmeh.org.

[5] Almusawi, H., 2014. Noor Center. Maintaining the Iraqi Traditional House. (P3).

[6] Shahin, B., 2011.Iraq Academic Scientific Journals. Engineering Journal. Volume 4. Book 17. 2011. p 156.

[7] Warren, J. and Fethi, I., 1982. Traditional houses in Baghdad. Horsham: Coach publishing house.

[8] Akram, O., Ismail, S., Franco, D., 2016. International Journal of Engineering Technology, Management and Applied Sciences. The Cultural Significant of Erbil City: Case of Traditional Kurdistan Houses. Volume 4. p 103-105.

[9] Mosul. Retrieved on Oct 5, 2017. https://ar.wikipedia.org/wiki/Mosul.

[10] Al-Mayahi, F., 2016.Khan Al-Itaishi, Karbala. https://annabaa.org/arabic/historic/7921.

[11] Wezha, B., 2016. Int. Journal of Engineering Research and Application www.ijera.com, Volume 6, Issue 9, ( Part-1) September 2016. Urban Courtyard Housing Form as a Response to Human Need, Culture and Environment in Hot Climate Regions: Baghdad. p 16. 
[12] Rogette, F., 2013. Traditional Domestic Architecture of the Arab Region. p 41-63.

[13] Salgın, B., Bayram,Ö., Akgün, A., Agyekum K.,2017. Sustainable Features of Vernacular Architecture: Housing of Eastern Black Sea Region. p 9. Art Journal, Turkey.

[14] Fletcher, B.,1896.A History of architecture for the student, craftsman, and amateur. London. p 30.

[15] Al-Taie, E., Al-Ansari, N., Knutsson S., 2012. Journal of Earth Sciences and Geotechnical Engineering, Volume 2, 2012, Materials and the Style of Buildings used in Iraq during the Islamic period. p 72-74.

[16] Abbasid architecture. Retrieved on Oct 5, 2017.https://en.wikipedia.org/wiki/Abbasid_architecture.

[17] Meir, L., Road, S., 2002. Thermal Comfort - Thermal Mass: Housing in Hot Dry Climates. Proceedings: Indoor Air 2002.p 1050-1055. https://www.researchgate.net/publication/267512638_thermal_comfort_thermal_mass_housing_in_hot_dry_climates

[18] Almusaed, A., Almssad, A., 2015.ScienceDirect, Case Study Building materials in eco-energy houses from Iraq and Iran.al-Basrah Technical house description. p 42-48.

[19] Al-Ansari, R., Almaoruth A., 2012. Journal, issue 53, 2012. Traditional Architecture of Iraq

[20] Abdulkareem, S., 2012. The Adaptation of Vernacular Design Strategies for Contemporary Building Design in Kurdistan. B.S. Thesis. Texas Tech University August, 2012.

[21] Al-Zarkani, K., 2012. Architecture of the Iraqi Traditional House - Al-Baghdadi and Al-Mosulli Houses as a case study.

[22] Al-Ansary, R., n.d.al-Najaf al-Ashraf: A study of the preeminent Architectural Features.

[23] Karbala architecture. p 1-12.www.holykarbala.net.

[24] Our Islamic Monuments, 2010.Islamic architecture and climate in architectural form. Retrieved on June, 12. 2017.http://www.startimes.com.

[25] Al-Taie, E., Al-Ansari, N., Knutsson, S., 2012. Journal of Earth Sciences and Geotechnical Engineering, Volume 2, 2012, The Progress of Buildings Style and Materials from the Ottoman and British Occupations of Iraq. ScienPress Ltd. p42. Retrieved on Sep, 9. 2017. www.news.farfesh.com.

[26] Yousuf, S., 1975. The Baghdadi Ancient House. Alturath Alshabi. No. 6. Volume VI. 1975. p 7.

[27] Al-Deywachi, S., 1975. The Mosuli House. Alturath Alshabi. No. 6.Volume VI. 1975. p 21

[28] Al-Hejjiyah, A, 1975. Disappeared Baghdadi Building Aspects. Alturath Alshabi. No. 6. Vol. VI. p 123.

[29] Al-Ansari, M., n.d. Folks Buildings in Kadhimiyah. Alturath Alshabi. No. 6.Volume VI. 1975. p 145.

[30] Shafej, J., n.d. Folks Buildings in Simawa. Alturath Alshabi. No. 6.Volume VI. 1975. p 183.

[31] Al-Telefari, A., n.d. Folks Buildings in Telefar. Alturath Alshabi. No. 6.Volume VI. 1975. p 195.

[32] Murad, H., 2015. Modelling and thermal optimization of traditional housing in a hot arid area. Thesis. University of Manchester. p 50.

[33] El-Shorbagy, A., 2010. International Journal of Civil \& Environmental Engineering Volume10 No:04. Traditional Islamic-Arab House: Vocabulary and Syntax. p 18.

[34] Tariq A., 2008. Al-najah National University. Analysis of the Palestinian architecture of residential buildings. p 31 43.Palestine.

[35] Ozorhon, G., Ozorhon, I., 2014. Learning from Mardin and Cumalıkızık: Turkish Vernacular Architecture in the Context of Sustainability. Arts Journal. 2014, p 175-189. www.mdpi.com/journal/arts. 